\title{
Effect of Reinsurance on Performance of General Insurance Companies: Evidence from Sri Lanka
}

\section{Badal Widanelage Chithrani Madhusha Amarasena}

Department of Accountancy and Finance, Faculty of Management Studies, Sabaragamuwa University of Sri Lanka P.O. Box. 02, Belihuloya, Sri Lanka

DOI - http://doi.org/10.37502/IJSMR.2021.4702

\begin{abstract}
The insurance companies tend to use a risk transferring mechanism to another capable insurer to get protection against their financial complications. Some insurance companies suspend and amalgamate with other companies due to unexpected catastrophes and growing their liability in the current scenario. By considering this situation, the researcher intended to examine the effect of reinsurance on the performance of the general insurance sector using the Sri Lankan evidence of 07 general insurance companies from 2010 to 2019. ROA and Underwriting profit/loss ratio was used as the proxies for the performance of the general insurance companies. The explanatory variable was reinsurance measured by retention ratio, net claims ratio, net commission ratio, and ceded reinsurance ratio. Findings were obtained through the panel data regression. It revealed that the net claims ratio has a significantly negative effect while the ceded reinsurance ratio has a significantly positive effect on the performance of general insurance companies. Further, the net commission ratio has a positive effect, while the retention ratio negatively affects general insurance companies' performance. So, this study concludes that general insurance companies should effectively manage the quality of the underwriting procedures and claim costs to increase their performance.
\end{abstract}

Keywords: Reinsurance; Performance of general insurance companies; net claims ratio; Ceded reinsurance ratio; underwriting profit/loss ratio; ROA

\section{Introduction}

Insurance companies spread their risks and protect themselves against extraordinary or unforeseen losses through reinsurance (Obonyo, 2016). Reinsurance can be defined as the insurance that a primary insurer purchases from another capable insurer to insulate from the risk of the event of a significant claim. Therefore, the use of reinsurance by insurers has substantial economic impacts and implications on their performance and decision-making. And without a doubt, reinsurance assists in reducing the unnecessary volatility or instability in the financial statements, particularly profit and loss statements (Kravych \& Sherris, 2004). And also, this connection of reinsurance and performance of the insurance companies benefits executive managers to make better-informed decisions and for executive management of 
IRCSL on how better to regulate the industry in terms of the policy as it pertains to reinsurance and performance of General insurance companies.

The primary insurers have to protect against their financial complications through reinsurance in their business routine. Some insurance companies suspended and amalgamated with other insurance companies in Sri Lanka during the last few years due to unexpected catastrophes and growing liability, thereby low performance. For instance, Union Assurance General Ltd amalgamated with Fair first Insurance Ltd in 2017. Janashakthi General Insurance Ltd amalgamated with AIG, and again, it amalgamated with Allianz Insurance Lanka Ltd since 2018. MBSL was suspended. Thus, Government rules also are imposed to increase their reinsurance portion. As per the government Gazette, all primary insurers are now required to cede $30 \%$ of their total reinsurance premium from every general reinsurance contract to NITF (IRCSL Report, 2018). The lack of research studies concentrating on reinsurance on general insurance companies in the Sri Lankan context also leaves a significant research gap. So, the researcher investigated the relationship between reinsurance and the performance of general insurance companies.

As reported by Munich Reinsurance, reinsurance enables all insurers to manage their financial burdens to the extent that none is faced with a financial burden that it cannot pay. Empirically, some developed countries and developing countries concentrated on the studies of the effect of reinsurance on the performance of insurance companies. Lee (2014) examined the firm-specific factors and macroeconomics that affect the profitability of Taiwanese property-liability insurance companies from 1999 to 2009. The study's findings show that underwriting risk, reinsurance usage, input cost, return on investment, and a member of a financial holdings group affect operating ratio and ROA significantly. Malik (2011) investigated the firm-specific factors determining the profitability of 34 insurance companies in Pakistan from 2005 to 2009. Research results indicate that the volume of capital and the company's size is positively and significantly related to profitability. Shiu (2009) investigated the linkage between insurer performances proxy by investment yield in the U.K. life insurance industry. The findings show that reinsurance dependence is negatively related to the investment yield. Although the foreign scholars concentrated on the studies of the effect of reinsurance on the performance of insurance companies, Sri Lankan scholars are less touched on this regard.

The objectives of this study are to identify the relationship between the retention ratio, net claim ratio, net commission ratio, ceded reinsurance ratio, and ROA and to identify the relationship between the retention ratio, net claim ratio, net commission ratio, ceded reinsurance ratio, and Underwriting profit/Loss Ratio. 


\section{Methodology}

The researcher used secondary data from 07 general insurance companies in Sri Lanka from 2010 to 2019 to carry out this study because some general insurance companies are restricted from collecting data. Findings were obtained through the panel data regression.

\begin{tabular}{|l|l|r|}
\hline \multicolumn{2}{|l|}{ Independent variable } \\
\hline
\end{tabular}

Figure 1. Conceptual Framework

ROA and Underwriting profit or loss ratio used as the proxies for the performance of the general insurance companies. The explanatory variable of the study was reinsurance measured by retention ratio, net claims ratio, net commission ratio, and ceded reinsurance ratio (Fig. 1). The Models can be developed as follows.

ROA $_{i t}=\beta_{0}+\beta_{1}$ CLAIM $_{\text {it }}+\beta_{2}$ CEDERE $_{i t}+\beta_{3}$ COMM $_{i t}+\beta_{4}$ RETEN $_{i t}+\varepsilon_{i t}$

$\mathrm{UNDWR}_{\mathrm{it}}=\beta_{0}+\beta_{1} \mathrm{CLAIM}_{\mathrm{it}}+\beta_{2} \mathrm{CEDERE}_{\mathrm{it}}+\beta_{3} \mathrm{COMM}_{\mathrm{it}}+\beta_{4} \mathrm{RETEN}_{\mathrm{it}}+\varepsilon_{\mathrm{it}}$

Where; ROA ${ }_{i t}, \mathrm{UNDWR}_{\mathrm{it}}, \mathrm{CLAIM}_{\mathrm{it}}, \mathrm{CEDERE}_{\mathrm{it}}, \mathrm{COMM}_{\mathrm{it}}, \mathrm{RETEN}_{\mathrm{it}}, \beta_{0}$, and $\varepsilon_{\mathrm{it}}$ indicate the Return on assets, Underwriting profit or loss ratio, Net claims ratio, Ceded reinsurance ratio, Net commission ratio, Retention ratio, constant term, and the error term.

\section{Results and Discussion}

Here, the researcher used ROA and the Underwriting Profit or Loss ratio as proxies for the performance of general insurance companies and used Pooled OLS Model, Fixed Effect Model, Random Effect Model, and Hausman Test to select the fitted model.

Table 1. Panel Data Regression

\begin{tabular}{llr}
\hline Panel Data Regression Technique & Model & Coefficient \\
\hline Pooled OLS Model & ROA Model & $0.0256^{*}$ \\
& Underwriting Profit/Loss Ratio Model & $0.0003^{*}$ \\
Fixed Effect Model & ROA Model & $0.0000^{*}$ \\
& Underwriting Profit/Loss Ratio Model & $0.0000^{*}$ \\
Random Effect Model & ROA Model & $0.0000^{*}$ \\
& Underwriting Profit/Loss Ratio Model & $0.0000^{*}$ \\
\hline
\end{tabular}

* - significant at $95 \%, * *$ - significant at $90 \%$

The results of Pooled OLS Model, Fixed Effect Model, and Random Effect Model reported in Table 1 show that both ROA Model and Underwriting Profit / Loss Ratio Model are significant. 
Table 2. Hausman Test

\begin{tabular}{ll}
\hline Model & Prob. \\
\hline ROA Model & $0.0851^{* *}$ \\
Underwriting Profit/Loss Ratio Model & $0.0049 *$ \\
\hline$*$ - significant at 95\%,** - significant at $90 \%$ &
\end{tabular}

The Hausman test was used to test the best model from Random Effect Model and Fixed Effect Model. If the Hausman test is significant, then the fixed effect model is the fitted model. The results of the Hausman Test reported in Table 2 shows that the fitted model is the fixed effect model for both ROA and Underwriting Profit / Loss Ratio.

Table 3. Fixed Effect Model

\begin{tabular}{lrr}
\hline Variable & ROA Model & Underwriting Profit/Loss Ratio Model \\
\hline Constant & 0.202513 & 0.231455 \\
Net Claim Ratio & $-0.366568^{*}$ & $-0.730292^{*}$ \\
Ceded Reinsurance Ratio & $0.061746^{*}$ & $0.554360^{*}$ \\
Net Commission Ratio & 0.106938 & 0.449062 \\
Retention Ratio & -0.063983 & -0.070593 \\
\hline
\end{tabular}

* - significant at $95 \%, * *$ - significant at $90 \%$

The results of the Fixed Effect Model reported in Table 3 show that the Net claim ratio carries a significant adverse effect on the ROA and Underwriting profit/loss ratio of general insurance companies. If a general insurance company incurs the high net claims, it means less the return on assets and underwriting profits earned by the companies. This result is consistent with Obonyo (2016) who found that "the higher the net claims incurred, the less the underwriting profits earned by the insurance company."

In contrast, Ceded reinsurance ratio carries a significant positive effect on the ROA and Underwriting profit/loss ratio of general insurance companies. It means that a high portion of ceding to a reinsurer is enabling the primary insurer to cover even catastrophic losses easily with the assistance of the reinsurer. Thus, the performance of general insurance companies is grown up because of the confidence of the clients. This result is consistent with Soye \& Adeyemo (2017), who found that "Ratio of Ceded Reinsurance has a positive impact on ROA of insurance companies. It is positively correlated with ROA".

Net commission ratio carries a positive effect on the ROA and Underwriting profit/loss ratio of general insurance companies. It means that Sri Lankan general insurance companies earn more reinsurance commissions than commission expenses to intermediaries. Its effect is not statistically significant in the Sri Lankan context. This result is consistent with Obony (2016) who found that "the net commission ratio positively affects the underwriting profit ratio. It implies that the more ceding commission received over commission paid out to the insurance brokers, the lower the loss incurred by the insurance company".

The retention ratio has a negative relationship with the ROA and Underwriting profit/loss ratio of general insurance companies in Sri Lanka. If a primary insurer retains more risk and cedes 
less risk to a reinsurer, the primary insurer must bear more losses than reinsurance. However, the results show that the retention ratio and the performance are not statistically significant. This result is consistent with Berger, Cummins, \& Tennyson (1992) and Elango, Ma, \& Pope (2008), who found out that "reinsurance contributes to the financial stability of an organization, implying that reducing the retention ratio can improve the financial performance of the insurance companies."

\section{Panel Data Regression Models}

\section{ROA Model}

$$
\begin{gathered}
\mathrm{ROA}_{\mathrm{it}}=0.202513-0.366568 \mathrm{CLAIM}_{\mathrm{it}}+0.061746 \mathrm{CEDERE}_{\mathrm{it}}+0.106938 \mathrm{COMM}_{\mathrm{it}}- \\
0.063983 \mathrm{RETEN}_{\mathrm{it}}+\varepsilon_{\mathrm{it}}
\end{gathered}
$$

\section{Underwriting Profit / Loss Ratio Model \\ $\mathrm{UNDWR}_{\mathrm{it}}=0.231455-0.730292 \mathrm{CLAIM}_{\mathrm{it}}+0.554360 \mathrm{CEDERE}_{\mathrm{it}}+0.449062 \mathrm{COMM}_{\mathrm{it}}-$ $0.070593 R_{E T E N}{ }_{i t}+\varepsilon_{\text {it }}$}

\section{Conclusion}

The main intention of this study was to examine the effect of reinsurance on the performance of the general insurance sector using evidence from Sri Lanka. The researcher used secondary data from 07 general insurance companies in Sri Lanka from 2010 to 2019 to carry out this study. ROA and Underwriting profit or loss ratio used as the proxies for the performance of the general insurance companies. The explanatory variable of the study was reinsurance measured by retention ratio, net claims ratio, net commission ratio, and ceded reinsurance ratio. Findings were obtained through the panel data regression, revealing that the net claims ratio has a significantly negative effect on the performance of general insurance companies. In contrast, Ceded reinsurance ratio has a significantly positive impact on the performance of general insurance companies. Further, the net commission ratio carries a positive effect, while the retention ratio carries a negative effect on the performance of general insurance companies. However, the effect is statistically insignificant in the Sri Lanka context. So, this study concludes that general insurance companies should effectively manage their quality of the underwriting procedures and claim cost to increase their performance.

Therefore, these implications are crucial to the top management of general insurance companies to enhance their performance. General insurers should employ quality and effective underwriting and claims management practices and guard against fraudulent claims by putting robust control systems in place. Also, Sri Lankan insurers should ensure that reinsurance commissions earned from reinsurance contracts cover acquisition costs.

Further, the researcher has suggested these suggestions for future researches also. So, if future researchers can expand the sample size and use different analytical tools, it is very successful for the new findings. Also, future researchers can do the investigation on the effect of reinsurance on the performance of the whole insurance industry. 


\section{References}

1) Berger, L., Cummins, J., \& Tennyson, S. (1992). Reinsurance and the liability insurance crisis. Journal of Risk and Uncertainty 5, pp. 253-272.

2) Elango, B., Ma, Y., \& Pope, N. (2008). An investigation into the diversificationperformance relationship in the US property-liability insurance industry. Journal of Risk and Insurance, 75(3), pp. 567-591.

3) Kravych, Y., \& Sherris, M. (2004). Enhancing Insurer Value Through Reinsurance Optimization in the presence of Frictional Cost . Australian Research Council.

4) Lee, C. Y. (2014). The effects of firm specific factors and macroeconomics on profitability of propertyliability insurance industry in Taiwan. Asian Economic and Financial Review vol. 4(5), pp. 681-691.

5) Malik, H. (2011). Determinants of Insurance Companies Profitability: An Analysis of Insurance Sector of Pakistan . Academic Research International, pp. 315-321.

6) Munich Reinsurance. [Online] Available from: https://www.munichre.com

7) Obony, S. N. (2016). The Effect of Reinsurance Programmes on Financial Performance of General Insurance Companies In Kenya. A Research Project Submitted In Partial Fulfillment of the Requirement for the Award of a Degree of Master of Science in Finance, School Of Business, University Of Nairobi.

8) Shiu, Y. M. (2009, June 24). Economic factors, firm characteristics and performance: a panel data analysis for United Kingdom life offices. Applied Economics Letters, pp. 1033-1037.

9) Soye, Y. A., \& Adeyemo, D. L. (2017). Evaluation of Impacy of Reinsurance Mechnism on Insurance Companies Sustainability in Nigeria. International Journal Research of Innovations and Sustainable Development, pp. 1-14, 187. 